\title{
Effect of sewage water irrigation on soil properties and evaluation of the accumulation of elements in Grass crop in Mysore city, Karnataka, India
}

\author{
Mohammed A. Alghobar ${ }^{1}$, Lathamani Ramachandra ${ }^{1}$, Sidduraiah Suresha ${ }^{2}$ \\ ${ }^{1}$ Department of Environmental Science, Yuvaraja's College, University of Mysore, Mysore 570005, Karnataka, India \\ ${ }^{2}$ Corresponding author. Peer review under responsibility of University of Mysore, Mysore, India
}

\section{Email address:}

sureshkumar12@yahoo.com (S. Suresha)

\section{To cite this article:}

Mohammed A. Alghobar, Lathamani Ramachandra, Sidduraiah Suresha. Effect of Sewage Water Irrigation on Soil Properties and Evaluation of the Accumulation of Elements in Grass Crop in Mysore City, Karnataka, India. American Journal of Environmental Protection. Vol. 3, No. 5, 2014, pp. 283-291. doi: 10.11648/j.ajep.20140305.22

\begin{abstract}
Use of sewage water for irrigation improved chemical properties and fertility status in soil. Sewage water contains elements essential for plant growth and also contains heavy metals which may be toxic for animals if their concentration exceeds than permissible limit. To monitor this situation, a survey was conducted to ascertain the addition of heavy metals into agricultural fields through sewage water irrigation for grass crop in the farmlands of selected areas of Vidyaranyapuram in Mysore city. The results indicated that in sewage water the permissible amounts of total $\mathrm{N}$, total $\mathrm{P}$ and potassium which are considered essential nutrients for productivity levels (grass growth) and soil fertility. The concentrations of heavy metals in the sewage water were in the proposed Food and Agriculture Organization range. The analysis showed that in soil concentration the irrigation with sewage water $(\mathrm{SW})$ and treated sewage water $(\mathrm{TSW})$ induces significant $(\mathrm{P}<0.05)$ decrease of soil $\mathrm{pH}$ when compared to MW and control treatment GW. The SW and TSW affect significantly the EC Indeed, in comparison with groundwater $(\mathrm{GW}), \mathrm{EC}$ is greater with SW and TSW treatment. For Major elements contents and fertilizer as observed in the irrigation with $\mathrm{SW}$ led to a significant increase of $\mathrm{Ca}, \mathrm{Na}, \mathrm{N}, \mathrm{P}, \mathrm{K}$ and $\mathrm{SO}_{4}$ in comparison with the control ground water (GW). For $\mathrm{Cl}$, in irrigation with $\mathrm{SW}$ has no effect on the $\mathrm{Cl}$ of soil. For heavy metals in comparison to the standard, the $\mathrm{SW}$ has no a significant $(\mathrm{P}<0.05)$ effect in all elements except significant increase was noticed for $\mathrm{Fe}$. In the grass, our investigation showed that irrigation with $\mathrm{SW}$ reuse led to a significant increase $(\mathrm{P}<0.05)$ of $\mathrm{N}, \mathrm{P}, \mathrm{K}, \mathrm{Ca}, \mathrm{Mg}$ and $\mathrm{Na}$ contents. Heavy metals shown in grass irrigated with sewage water ( $\mathrm{SW}$ ) caused a significant increase $(\mathrm{p}<0.05)$ of $\mathrm{Fe}, \mathrm{Mn}, \mathrm{Cu}, \mathrm{Zn}$ and $\mathrm{Pb}$ as compared to irrigated ground water $(\mathrm{GW})$. Where was no significant effect in growth of the grass as shown for heavy metals concentrations as $\mathrm{Cd}$, Ni, $\mathrm{Co}$ and $\mathrm{Cr}$.
\end{abstract}

Keywords: Heavy Metals, Irrigation, Sewage Water, Grass, Soil

\section{Introduction}

Sewage water is used as potential source irrigation for raising vegetables and fodder crops around the sewage treatment sites which are directly or indirectly consumed by human beings. Raw Sewage is a rich source of organic and inorganic nutrients for plant growth; sewage farming is quite common in all urban areas in India. Some cities sewage water where industrial effluent is discharged along with may contain toxic metals in high amounts. Thus the composition of domestic sewage may vary with the type of industrial discharge their waste $[1,2]$. The analysis of eight chemical parameters of untreated sewage water was carried out in Vidyaranyapuram STP, Mysore, India. Factor analysis was applied on untreated sewage water. Data matrix, pollution factor was found to be the most contributing factor and it showed $22.31 \%$ of the total variance (Chloride, BOD, COD and TDS). The second most contributing factor was found to be the nitrification factor, which explained $21.11 \%$ of the total variance ( $\mathrm{pH}$ and Nitrate), whereas the salinization factor contributed $16.98 \%$ of the total variance (TS and TSS) [3]. Sewage has high values of temperature, $\mathrm{pH}$, hardness, alkalinity, chemical oxygen demand, total soluble salts, nitrates, nitrites and cations like sodium, potassium, calcium and magnesium [4]. 
The sewage water has a high fertility load; it adds available $\mathrm{N}, \mathrm{P}, \mathrm{K}, \mathrm{Fe}, \mathrm{Mn}, \mathrm{Zn}$ and $\mathrm{Cu}$ to soil, this indicating their significant addition through sewage suggesting use of sewage water as a low grade cheap fertilizer in agriculture. It can drastically reduce the cost due to substitution of chemical fertilizers. The concentration of heavy metals such as $\mathrm{Cu}, \mathrm{Pb}$ and Co in plant tissue was low compared to limits standards. These heavy metal concentrations are well below hazardous levels $[5,6]$. The effect of continuous irrigation with sewage water increases exchangeable cations to a large extent $[7,8]$. Sewage water application increases the soil salinity, organic carbon, $\mathrm{N}, \mathrm{K}, \mathrm{Ca}, \mathrm{Mg}$ cations to a lot. Soil is a biofilter that can reduce a large part of domestic waste water pollutants, but this filtering increase $\mathrm{EC}, \mathrm{SAR}, \mathrm{Na}, \mathrm{Ca}$ and $\mathrm{Mg}$ of soil. In addition to these, sewage water also contains significant amounts of toxic metals such as arsenic, chromium, cadmium, copper, lead, nickel, zinc, cobalt, magnesium and iron [9]. And after accumulating in soil, get transferred to vegetables growth on these soils [10] similar results were reported [11].

Many studies have shown that sewage water irrigation has elevated the levels of heavy metals in receiving soils [12, 13]. Some of these metals after accumulating in the soil are transferred to food chain which can cause serious health hazards to human beings and animals. Besides these metals induce deficiency of other nutrients e.g., copper, iron and manganese inhibit plant uptake of zinc, possibly because of competition for the same carrier site in soil-water system [14]. Metals like iron, manganese, cobalt, copper and nickel are essential nutrients; however, their permissible limits are quite low and in living organisms [15]. The absorption of heavy metals by plants depends on a wide range of soil factors such as $\mathrm{pH}$, organic matter, soil metals availability and cation exchange capacity. The uptake of heavy metals also depends on season and presence of other heavy metals in soil [16, 17].The toxic levels of nickel and chromium show drastic effect on dry matter production and yield. Now it is our responsibility to advocate the proper use of sewage effluents in order to avoid soil contamination [18].

This study has been conducted to investigate the accumulation of chemical elements in grass, with different water qualities. Therefore, our main objective has been to study and assess the accumulation level of chemical elements in soil and grass, which were irrigated by sewage water as compared to non-sewage (ground water) in Mysore city.

\section{Materials and Methods}

\subsection{Study Sites}

The study was conducted around Vidyaranyapuram sewage treatment plant situated in a suburban area in the south western of Mysore (latitude 12.273681 to $12.270031^{\circ} \mathrm{N}$ and longitude 76.650737 to $76.655947^{\circ} \mathrm{E}$ ) was constructed in 2002 with an area of $27.21 \mathrm{sq}$. km and a sewer length of 7000 meters. It is a biological treatment plant situated next to the solid waste disposal area at the foothills of Chamundi Hills; the treated wastewater of Vidyaranyapuram sewage treatment plant crosses the Dalvai Lake and reaches drinking water source that is the Kabini River. The southwestern drainage connects to 67.65 million liters per day Vidyaranyapuram sewage treatment plant. More than fifty percent of the sewage generated in Mysore city is received by Vidyaranyapuram sewage treatment plant. Although the capacity of sewage treatment plant is 67.75 million liters per day the inflow rate of wastewater varies with many influencing factors like seasonal changes, tourist inflow etc., however there will be an approximate difference of 7 to 9 million liters per day between the raw wastewater received and the treated wastewater liberated due to seepage [3]. Farmers use this untreated wastewater for irrigation.

\subsection{Water, Soil and Grass Sampling and Analysis}

Samples of water used for irrigating soil and grass, cultivation were randomly collected from the farmlands. The samples were collected during January-August of the year 2013; experiment consisted of four treatments with three replicates, randomized complete block design (RCBD) with split plot arrangements.

Water: Sampling and analysis are carried out for each of the different water types used for irrigating the crops during the course of the experiment. All water samples were collected from the four types of water: sewage water (SW), mixed water (sewage water and pure water)(MW), treated sewage water(TSW) and ground water(GW), filled in $2000 \mathrm{ml}$ polythene bottles and transported immediately for laboratory analysis. The samples were analyzed for parameters such as concentrations of EC, $\mathrm{pH}$, soluble ions, and soluble and total phosphorous were determined. Biological oxygen demand (BOD), Chemical oxygen demand (COD), TDS, $\mathrm{CO}_{3}, \mathrm{HCO}_{3}$, $\mathrm{Na}, \mathrm{Mg}, \mathrm{Ca}$, and heavy metal were determined according to [19] standard methods. The filtrate was analyzed for the contents of $\mathrm{Fe}, \mathrm{Mn}, \mathrm{Zn}, \mathrm{Cu}, \mathrm{Ni}, \mathrm{Pb}, \mathrm{Co}, \mathrm{Cd}$, and $\mathrm{Cr}$ using ICP-OES (Perkin Elemer model 8000 DV).

Soil: Soil samples were collected randomly at each place and time the grass were plucked by using an Auger and uprooted and soil mixed thoroughly. The soil samples were air dried ground and sieved through $2 \mathrm{~mm}$ sieve. The prepared soil samples were then stored in polyethylene bottles for analysis of $\mathrm{pH}, \mathrm{EC}$, exchangeable bases $(\mathrm{K}, \mathrm{Ca}, \mathrm{Mg}, \mathrm{Na}), \mathrm{Cl}$, TN, TP, $\mathrm{SO}_{4}$ and Heavy metals. Soil samples were analyzed for measuring concentrations of heavy metals, including Fe, $\mathrm{Mn}, \mathrm{Zn}, \mathrm{Cu}, \mathrm{Cd}, \mathrm{Ni}, \mathrm{Pb}, \mathrm{Co}$, and $\mathrm{Cr}$. were determined after digestion using the Hossner method [20]. Total concentrations of $\mathrm{Fe}, \mathrm{Mn}, \mathrm{Zn}, \mathrm{Cu}, \mathrm{Cd}, \mathrm{Ni}, \mathrm{Pb}, \mathrm{Co}$, and $\mathrm{Cr}$ in the dissolved solution were measured using inductively coupled plasma atomic emission spectrometry (ICP-OES, Perkin Elemer model $8000 \mathrm{DV})$. Quality assurance and quality control for metals in soil samples were estimated by determining the metal contents in blank and duplicate samples and standard reference materials.

Plant: Grass leaves samples were hand harvested. All the collected samples of grass leaves were washed with double distilled water to remove airborne pollutants. All the samples were then oven-dried in a hot air oven at $70-80^{\circ} \mathrm{C}$ for $24 \mathrm{~h}$, to 
remove all moisture. Dried samples were powdered using a mortar and pestle and sieved through muslin cloth. Digestion of samples of grass, the dry ash method [21] was used to prepare the samples for determination of heavy metal concentration in the ground water and wastewater irrigated grass. For the digestion of grass samples, wet digestion method was used followed by ICP-OES. For each analysis $0.5 \mathrm{~g}$ of the sample was accurately weighed and digested with $1 \mathrm{ml}$ of perchloric acid $\left(\mathrm{HClO}_{4}\right)$ and $4 \mathrm{ml}$ of Nitric $\left(\mathrm{HNO}_{3}\right)$. The samples were allowed to cool and the contents were filtered off using Whatman 42 filter paper. The filtrate was made to $25 \mathrm{ml}$ with distilled water. Blank solution was made using the same procedure except the addition of vegetable sample. The plant material was then treated in the same way as of soil samples.

\subsection{Statistical Analysis}

All the data were statistically analyzed by analysis of variance (ANOVA) as applicable to a completely randomized block design (CRBD) Means were compared using Duncan's multiple range tests [22]. Statistical significance was defined as $\mathrm{p}<0.05$.

\section{Results and Discussion}

\subsection{Chemical Properties of the Used Sewage Effluents and Ground Water}

The result of chemical properties analysis of the sewage water that was used for irrigation at the contaminated sites is given in Table 1. The sewage water was compared with FAO standard for irrigation $[23,24]$ there were obvious differences in many measured parameters from site to site. The values of (BOD) and (COD) (Table 1) in (SW) was very high; the (DO) and (TDS) content of (SW), (TSW), (MW) and (GW) was very low when compared to the FAO values (1992). These results were in agreement with [25] who reported that Physico-chemical properties like total TSS, BOD and COD showed higher values in untreated sewage water compared to groundwater. The all treatments (SW, TSW, MW and GW) had optimum $\mathrm{pH}$ for irrigation based on FAO (1992) tolerance limit of $\mathrm{pH}$ of water samples for irrigation showed be 6.50 to 8.40. The $\mathrm{pH}$ of the treatment (MW) was 9.19, indicating alkaline nature of the mix water in the Lake. Also the EC was $\left(1032,1225,906\right.$ and $\left.1099 \mu \mathrm{s} / \mathrm{cm}^{-1}\right)$ were high when compared to the [23]. The sewage water contains considerable amounts of total $\mathrm{N}$, total $\mathrm{P}$ and potassium which are considered essential nutrients for productivity levels (grass growth) and soil fertility. The same results were reported by [4] shows that sewage has often high values of temperature, $\mathrm{pH}$, hardness, alkalinity, chemical oxygen demand, total soluble salts, nitrates, nitrites and cations like sodium, potassium, calcium and magnesium. Concentrations of heavy metals in the sewage water were in the proposed Food and Agriculture Organization range. But with continuous application of wastewater these metallic elements could get accumulated in the soil and grass. Same results were reported by [26] who found that even though there are low concentrations of heavy metals in irrigation water, its long term use caused heavy metal contamination leading to health risk of consumers.

\subsection{Effect of Sewage Water Irrigation on Distribution of Macro Elements and Heavy Metals in Soil}

The $\mathrm{pH}$ results are in table 2 . The irrigation with $\mathrm{SW}$ and TSW induces significant $(\mathrm{P}<0.05)$ decrease of soil $\mathrm{pH}$ with comparison to MW and control treatment GW. Similar results were noticed by $[27,28]$ who reported that after irrigation with different dilution of sewage water, $\mathrm{pH}$ decreased significantly. The reason for decreasing of soil $\mathrm{pH}$ may be due to decomposition of organic matter and production of organic acids in soils irrigated with wastewater [29, 30]. The SW and TSW affect significantly the EC (Table 2). Indeed, in comparison with groundwater $(\mathrm{GW}), \mathrm{EC}$ is greater with $\mathrm{SW}$ and TSW treatment. These results were in agreement with several authors like $[31,32,33,34]$. According to this increase in EC for soil irrigated with wastewater compared with soil irrigated with fresh water.

For Major elements contents and nutrients fertilizer as observed in table 3, the irrigation with $\mathrm{SW}$ led to a significant increase of $\mathrm{Ca}, \mathrm{Na}, \mathrm{N}, \mathrm{P}, \mathrm{K}$ and $\mathrm{SO}_{4}$ in comparison with the control (GW). For $\mathrm{Cl}$, the irrigation with $\mathrm{SW}$ has no effect on the $\mathrm{Cl}$ of soil. The significant $(\mathrm{P}<0.05)$ increase were in particular concerned $\mathrm{Ca} 0.93 \%$, Na 0.072 , N $0.49 \%$, P 0.078 , $\mathrm{K} 0.075 \%$ and $0.0023 \%$ for $\mathrm{SO}_{4}$ in comparison to the control (GW). The same results were reported by $[35,36]$ they found that the EC, total $\mathrm{N}$, and available $\mathrm{P}$ concentrations increased significantly in sewage water irrigation treatment compared to other treatments. also Similar results were noticed by [33] who investigated the effect of treated sewage water on soil and corn crop, the irrigation with treated wastewater increased significantly $(\mathrm{P}<0.05)$ the soil $\mathrm{EC}$, major element contents as $\mathrm{Na}, \mathrm{Cl}, \mathrm{Ca}, \mathrm{Mg}$ and fertilizer elements as $\mathrm{N}, \mathrm{P}$ and $\mathrm{K}$. This observations was confirmed by [37] reported that irrigation using raw sewage water probably increases soil organic matter, nitrogen and concentrations of major cations.

Table 1. Chemical analysis of water samples

\begin{tabular}{|c|c|c|c|c|c|c|c|}
\hline No. & parameters & Unit & $\begin{array}{l}\text { Sewage water } \\
\text { (SW) }\end{array}$ & $\begin{array}{l}\text { Treated Sewage } \\
\text { water (TSW) }\end{array}$ & $\begin{array}{l}\text { Mixed Water } \\
(\mathrm{MW})\end{array}$ & $\begin{array}{l}\text { Ground water } \\
\text { (GW) }\end{array}$ & $\begin{array}{l}\text { Standard Limit for } \\
\text { irrigation }[23,24]\end{array}$ \\
\hline 1. & $\mathrm{~T}$ & ${ }^{\circ} \mathrm{C}$ & 25 & 25 & 25 & 25 & \\
\hline 2. & $\mathrm{pH}$ & --- & 7.50 & 8.13 & 9.19 & 8.30 & $6.5-8.4$ \\
\hline 3. & $\mathrm{EC}$ & $\mu \mathrm{s} / \mathrm{cm}^{-1}$ & 1032 & 1225 & 906 & 1099 & $<3000$ \\
\hline 4. & DO & $\mathrm{mgL}^{-1}$ & Nil & 2.3 & 3.3 & 6.9 & $<9$ \\
\hline 5. & COD & $\mathrm{mgL}^{-1}$ & 964 & 145 & 281 & 16 & $80-500$ \\
\hline 6. & BOD & $\mathrm{mgL}^{-1}$ & 650 & 30 & 60 & 2 & 100 \\
\hline
\end{tabular}




\begin{tabular}{|c|c|c|c|c|c|c|c|}
\hline No. & parameters & Unit & $\begin{array}{l}\text { Sewage water } \\
\text { (SW) }\end{array}$ & $\begin{array}{l}\text { Treated Sewage } \\
\text { water (TSW) }\end{array}$ & $\begin{array}{l}\text { Mixed Water } \\
\text { (MW) }\end{array}$ & $\begin{array}{l}\text { Ground water } \\
\text { (GW) }\end{array}$ & $\begin{array}{l}\text { Standard Limit for } \\
\text { irrigation }[23,24]\end{array}$ \\
\hline 7. & TDS & $\mathrm{mgL}^{-1}$ & 560 & 624 & 504 & 696 & 2,000 \\
\hline 8. & $\mathrm{Ca}$ & $\mathrm{mgL}^{-1}$ & 43.37 & 62.64 & 27.30 & 56.22 & 400 \\
\hline 9. & $\mathrm{Mg}$ & $\mathrm{mgL}^{-1}$ & 27.01 & 28.89 & 41.46 & 68.50 & 60 \\
\hline 10. & $\mathrm{Na}$ & $\mathrm{mgL}^{-1}$ & 48 & 60 & 56 & 56 & 900 \\
\hline 11. & K & $\mathrm{mgL}^{-1}$ & 24 & 20 & 12 & 20 & 0.2 \\
\hline 12. & $\mathrm{CO}_{3}$ & $\mathrm{mgL}^{-1}$ & Nil & Nil & 48 & 40 & 6 \\
\hline 13. & $\mathrm{HCO}_{3}$ & $\mathrm{mgL}^{-1}$ & 296 & 392 & 204 & 544 & 600 \\
\hline 14. & $\mathrm{Cl}$ & $\mathrm{mgL}^{-1}$ & 93 & 115 & 117 & 17 & 1100 \\
\hline 15. & $\mathrm{TN}$ & $\mathrm{mgL}^{-1}$ & 78.4 & 61.6 & 11.2 & 0.56 & 30 \\
\hline 16. & TP & $\mathrm{mgL}^{-1}$ & 4.55 & 2.40 & 0.89 & 0.053 & 2 \\
\hline 17. & $\mathrm{SO}_{4}$ & $\mathrm{mgL}^{-1}$ & 24 & 20 & 16 & 52 & 1000 \\
\hline 18. & $\mathrm{Fe}$ & $\mathrm{mgL}^{-1}$ & 2.93 & 2.48 & 2.39 & 0.075 & 5 \\
\hline 19. & $\mathrm{Mn}$ & $\mathrm{mgL}^{-1}$ & 0.157 & 0.041 & 0.068 & 0.043 & 0.2 \\
\hline 20. & $\mathrm{Cu}$ & $\mathrm{mgL}^{-1}$ & $<0.05$ & $<0.05$ & $<0.05$ & $<0.05$ & 0.1 \\
\hline 21. & $\mathrm{Zn}$ & $\mathrm{mgL}^{-1}$ & 0.133 & 0.278 & 0.356 & 0.363 & 2 \\
\hline 22. & $\mathrm{Cd}$ & $\mathrm{mgL}^{-1}$ & 0.047 & 0.047 & 0.048 & 0.047 & 0.01 \\
\hline 23. & $\mathrm{Ni}$ & $\mathrm{mgL}^{-1}$ & 0.040 & 0.036 & 0.038 & 0.034 & 5 \\
\hline 24. & $\mathrm{~Pb}$ & $\mathrm{mgL}^{-1}$ & 0.053 & 0.053 & 0.052 & 0.051 & 2 \\
\hline 25. & Co & $\mathrm{mgL}^{-1}$ & 0.055 & 0.054 & 0.053 & 0.054 & 0.05 \\
\hline 26. & $\mathrm{Cr}$ & $\mathrm{mgL}^{-1}$ & 0.032 & 0.031 & 0.031 & 0.032 & 0.1 \\
\hline
\end{tabular}

Table 2. Mean values of Chemical properties of soils irrigated with different water

\begin{tabular}{|c|c|c|c|c|c|c|}
\hline No. & parameters & Unit & Soil SW & Soil TSW & Soil MW & Soil GW \\
\hline 1. & $\mathrm{pH}$ & $\begin{array}{c}-- \\
\end{array}$ & $6.64 \mathrm{c}$ & $7.36 \mathrm{~b}$ & $7.88 \mathrm{a}$ & $7.90 \mathrm{a}$ \\
\hline 2. & $\mathrm{EC}$ & $\mu \mathrm{s} / \mathrm{cm}^{-1}$ & $306 \mathrm{a}$ & $218 \mathrm{~b}$ & $203 \mathrm{c}$ & $190 \mathrm{c}$ \\
\hline 3. & $\mathrm{Ca}$ & $\%$ & $0.93 \mathrm{a}$ & $0.91 \mathrm{a}$ & $0.76 \mathrm{~b}$ & $0.79 \mathrm{~b}$ \\
\hline 4. & $\mathrm{Mg}$ & $\%$ & $0.50 \mathrm{~b}$ & $0.4 \mathrm{cb}$ & $0.44 \mathrm{c}$ & $0.54 \mathrm{a}$ \\
\hline 5. & $\mathrm{Na}$ & $\%$ & $0.072 \mathrm{a}$ & $0.052 \mathrm{~b}$ & $0.056 \mathrm{~b}$ & $0.026 \mathrm{c}$ \\
\hline 6. & K & $\%$ & $0.075 \mathrm{a}$ & $0.072 \mathrm{a}$ & $0.041 \mathrm{c}$ & $0.054 \mathrm{~b}$ \\
\hline 7. & $\mathrm{Cl}$ & $\%$ & $0.001 \mathrm{~b}$ & $0.002 \mathrm{a}$ & $0.002 \mathrm{a}$ & $0.002 \mathrm{a}$ \\
\hline 8. & $\mathrm{TN}$ & $\%$ & $0.49 \mathrm{a}$ & $0.39 \mathrm{~b}$ & $0.080 \mathrm{c}$ & $0.044 \mathrm{c}$ \\
\hline 9. & TP & $\%$ & $0.078 \mathrm{a}$ & $0.050 \mathrm{~b}$ & $0.022 \mathrm{~d}$ & $0.028 \mathrm{c}$ \\
\hline 10 & $\mathrm{SO}_{4}$ & $\%$ & $0.0023 \mathrm{a}$ & $0.0020 \mathrm{a}$ & $0.0010 \mathrm{~b}$ & $0.0010 \mathrm{~b}$ \\
\hline 11. & $\mathrm{Fe}$ & $\mathrm{mg} / \mathrm{kg}^{-1}$ & $41800 \mathrm{a}$ & $40100 \mathrm{~b}$ & $42300 \mathrm{a}$ & $39700 \mathrm{~b}$ \\
\hline 12. & $\mathrm{Mn}$ & $\mathrm{mg} / \mathrm{kg}^{-1}$ & $<0.05 \mathrm{a}$ & $<0.05 \mathrm{a}$ & $<0.05 \mathrm{a}$ & $<0.05 \mathrm{a}$ \\
\hline 13. & $\mathrm{Cu}$ & $\mathrm{mg} / \mathrm{kg}^{-1}$ & $<0.05 \mathrm{a}$ & $<0.05 \mathrm{a}$ & $<0.05$ a & $<0.05 \mathrm{a}$ \\
\hline 14. & $\mathrm{Zn}$ & $\mathrm{mg} / \mathrm{kg}^{-1}$ & $<0.05 \mathrm{a}$ & $<0.05 \mathrm{a}$ & $<0.05 \mathrm{a}$ & $<0.05 \mathrm{a}$ \\
\hline 15. & $\mathrm{Cd}$ & $\mathrm{mg} / \mathrm{kg}^{-1}$ & $<0.05 \mathrm{a}$ & $<0.05 \mathrm{a}$ & $<0.05$ a & $<0.05 \mathrm{a}$ \\
\hline 16. & $\mathrm{Ni}$ & $\mathrm{mg} / \mathrm{kg}^{-1}$ & $<0.05 \mathrm{a}$ & $<0.05 \mathrm{a}$ & $<0.05 \mathrm{a}$ & $<0.05 \mathrm{a}$ \\
\hline 17. & $\mathrm{~Pb}$ & $\mathrm{mg} / \mathrm{kg}^{-1}$ & $<0.05 \mathrm{a}$ & $<0.05 \mathrm{a}$ & $<0.05 \mathrm{a}$ & $<0.05 \mathrm{a}$ \\
\hline 18. & Co & $\mathrm{mg} / \mathrm{kg}^{-1}$ & $<0.05 \mathrm{a}$ & $<0.05 \mathrm{a}$ & $<0.05$ a & $<0.05 \mathrm{a}$ \\
\hline 19 & $\mathrm{Cr}$ & $\mathrm{mg} / \mathrm{kg}^{-1}$ & $<0.05 \mathrm{a}$ & $<0.05 \mathrm{a}$ & $<0.05 \mathrm{a}$ & $<0.05 \mathrm{a}$ \\
\hline
\end{tabular}

Different letters within the same rows followed by mean values indicate significant differences by Duncan's multiple range tests at $\mathrm{P}<0.05$.
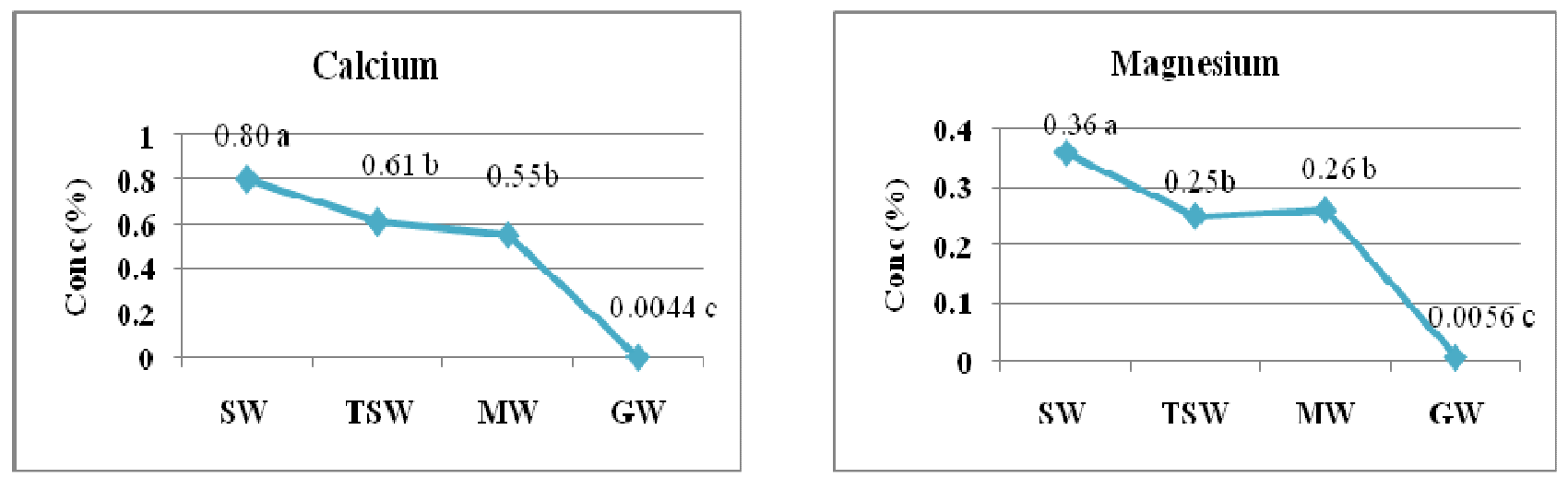

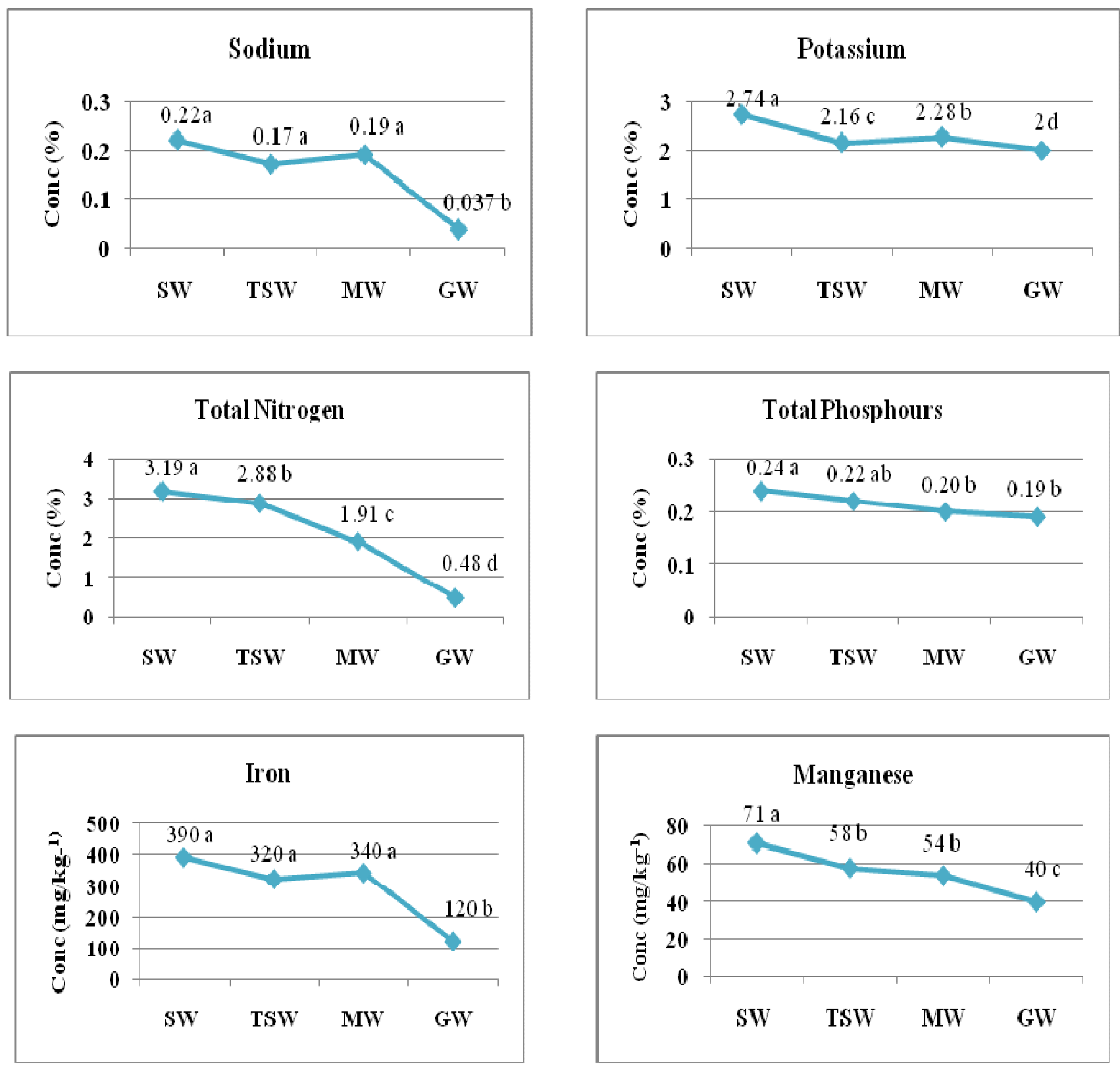

Different letters within the same Figure followed by mean values indicate significant differences by Duncan's multiple range tests at $\mathrm{P}<0.05$

Figure 1. Mean concentration of (Ca, Mg, Na, K, N, P, Fe and Mn) in Grass
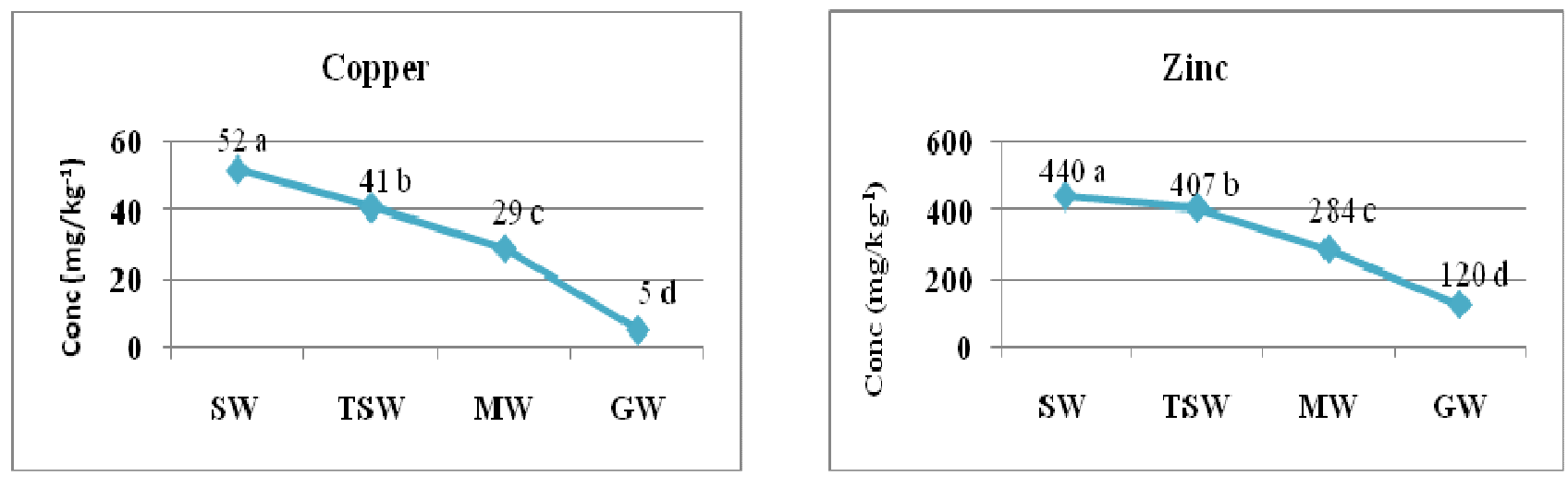

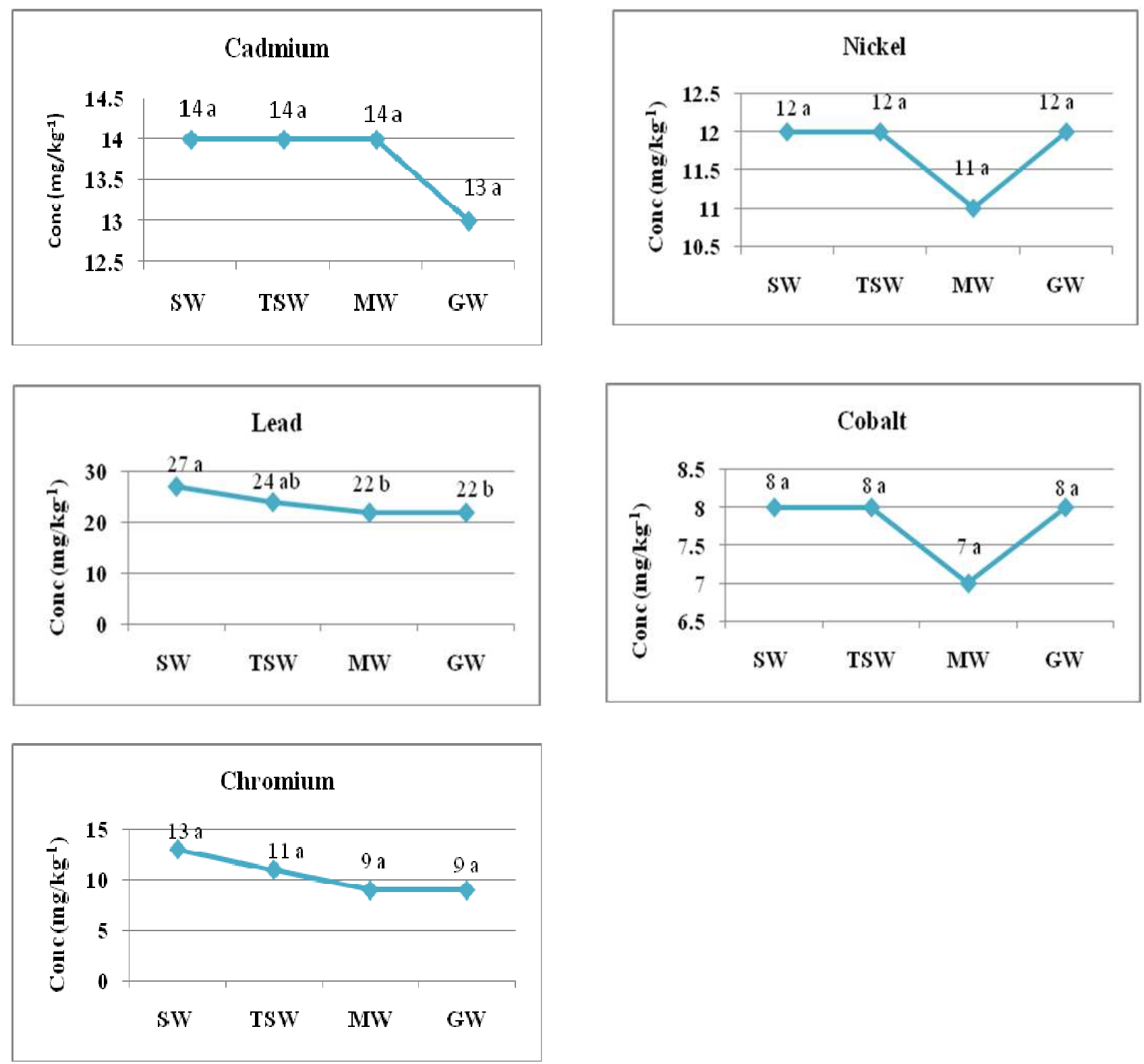

Different letters within the same Figure followed by mean values indicate significant differences by Duncan's multiple range tests at $\mathrm{P}<0.05$

Figure 2. Mean concentration of ( $\mathrm{Cu}, \mathrm{Zn}, \mathrm{Cd}, \mathrm{Ni}, \mathrm{Pb}$, Co and $\mathrm{Cr}$ ) in Grass

Our investigation was in agreement with the previous works obtained by $[38,39,40]$ who reported that irrigation with sewage water increased soil salinity, exchangeable $\mathrm{Na}, \mathrm{K}, \mathrm{Ca}$, $\mathrm{Mg}$, plant available phosphorus and decreased the soil $\mathrm{pH}$. For the heavy metal in comparison to the control, the SW has no a significant $(\mathrm{P}<0.05)$ effect in all elements (Table 2). Except significant increase was noticed for $\mathrm{Fe}$, about $4.48 \%$. This is due to levels of heavy metals in the wastewater are quite low, the irrigated soil shows lower concentrations of heavy metals. But may be due to the accumulation of heavy metals in the soil due to long-term irrigation. Similar results were noticed by [41, $42,36,34]$ who investigated the effect of sewage water on the soil chemical properties in an arid region. They reported that the sewage water reuse showed no effect on the increase of these elements during growing season.

\subsection{Metal Concentration in Grass}

The results of the nutrients and heavy metals content in grass crop for treatments of the sewage water irrigated and control area are presented in Fig. 1, According to Fig. 1, the irrigation with SW showed a significant $(p<0.05)$ increase of $\mathrm{N}, \mathrm{P}$ and $\mathrm{K}$ on leaves of the grass. The amount of total $\mathrm{N}$ was $4.90 \%$, for SW, 0.30 for total $\mathrm{P}$ and $\mathrm{K} 3.47 \%$, compared to treatment $\mathrm{SW}$. also $\mathrm{Ca}, \mathrm{Mg}$ and $\mathrm{Na}$ significant differences was higher noted between the SW treatment and the control (Fig. 1). In grass, our investigation showed that irrigation with $\mathrm{SW}$ reuse led to a significant increase $(\mathrm{P}<0.05)$ of $\mathrm{N}, \mathrm{P}, \mathrm{K}, \mathrm{Ca}, \mathrm{Mg}$ and $\mathrm{Na}$ contents in grass. Similar results were observed by [43] on Sunflower crop and [34] on forage crops.

The range and mean concentrations of heavy metals (in 
$\mathrm{mg} / \mathrm{kg}^{-1}$ dry weight) in sewage water irrigated grass are presented in Fig. 1,2. The mean concentration (in $\mathrm{mg} / \mathrm{kg}^{-1}$ dry weight) of heavy metals in grass ranged between 390 and 120 for $\mathrm{Fe}, 71$ to 40 for $\mathrm{Mn}, 52$ to 5 for $\mathrm{Cu}, 440$ to 120 for $\mathrm{Zn}, 14$ to 13 for $\mathrm{Cd}, 12$ to 11 for $\mathrm{Ni}, 27$ to 22 for $\mathrm{Pb}, 8$ to 7 for $\mathrm{Co}$ and 13 to 9 for Cr. Heavy metals shown in Fig. 3, grass irrigated with SW caused a significant increase $(\mathrm{p}<0.05)$ of $\mathrm{Fe}, \mathrm{Mn}, \mathrm{Cu}$, $\mathrm{Zn}$ and $\mathrm{Pb}$ as compared to irrigated ground water. While no significant effect in content the grass was shown for heavy metal concentrations as $\mathrm{Cd}, \mathrm{Ni}, \mathrm{Co}$ and $\mathrm{Cr}$ (Fig. 3). The findings were in conformity with the earlier studies reported by [25] on potato crop, [44] on green vegetables. [45] on Brassica cultivars, [46] on grass, [1] on greater in leafy vegetables than in grain crops. [47] on vegetables, [40] showed that sewage water irrigation treatments increase the availability of phosphorus and microelements as well as $\mathrm{N}, \mathrm{P}$, $\mathrm{K}, \mathrm{Ca}, \mathrm{Mg}, \mathrm{Na}, \mathrm{Fe}, \mathrm{Mn}, \mathrm{Zn}, \mathrm{Cu}$, to plant which lead to increase of cauliflower and red cabbage yields. [33] Showed that irrigation with treated sewage water led to significant increase of majors elements contents as $\mathrm{Na}, \mathrm{Cl}, \mathrm{Ca}, \mathrm{Mg}$ and fertilizer elements as $\mathrm{N}, \mathrm{P}$ and $\mathrm{K}$ and heavy metals such as $\mathrm{Cu}, \mathrm{Zn}, \mathrm{Co}$, $\mathrm{Cd}, \mathrm{Pb}$ and $\mathrm{Ni}$ on corn. [48] Revealed that wastewater irrigated soil wastewater and vegetables grown at wastewater zone. In vegetables grown in wastewater, the extent of heavy metal was enriched with $\mathrm{Mn}, \mathrm{Cu}, \mathrm{Zn}, \mathrm{Pb}, \mathrm{Cd}, \mathrm{Ni}, \mathrm{Co}$ and $\mathrm{Cr}$.

\section{Conclusion}

The present results is to compare the influence and the difference between chemical elements levels in soil and the grass crop that results from applying wastewater, treated wastewater and mix water (wastewater with pure water) and pure water when they are used for irrigation in Vidyaranyapuram sewage treatment plant, situated at a suburban area in the south western of Mysore. The used water sources evaluated as a source of irrigation water according to the FAO system of water quality classification which appeared the suitable use of these sources in leaching and irrigation the saline soils especially in the short-time. The result showed that the soil parameters are significantly affected by application of sewage water irrigation. Irrigation with sewage water increased the concentrations of $\mathrm{pH}$, electrical conductivity, total $\mathrm{N}$, total $\mathrm{P}, \mathrm{K}, \mathrm{Ca}, \mathrm{Na}, \mathrm{SO}_{4}$ and $\mathrm{Fe}$, in soils irrigated by sewage water grown grass crop, compared to the control treatment. For the heavy metal in comparison to the control, the SW has no a significant $(\mathrm{P}<0.05)$ effect in all elements, except significant increasing was noticed for Fe. The results of the nutrients and heavy metals content in grass crop for treatments of the sewage water irrigated and control area are showed that irrigation with $\mathrm{SW}$ reuse led to a significant increase $(\mathrm{P}<0.05)$ of $\mathrm{N}, \mathrm{P}, \mathrm{K}, \mathrm{Ca}, \mathrm{Mg}$ and $\mathrm{Na}$ contents in grass. The accumulation of heavy metals such as of $\mathrm{Fe}, \mathrm{Mn}, \mathrm{Cu}, \mathrm{Zn}$ and $\mathrm{Pb}$ in grass was significant increase by sewage water irrigation. It could be concluded that in sewage water grown grass, uptake of metals may increase nutritional value and improves soil properties, plant growth, and yield without any contamination in soil and toxicity in grass crop.

\section{References}

[1] Antil, R. S., 2012. Impact of Sewage and Industrial Effluents on Soil-Plant Health, Industrial Waste, Prof. Kuan-Yeow Show (Ed.), ISBN: 978-953-51-0253-3, InTech. Available from: http://www.intechopen.com/books/industrial-waste/impact-ofsewer-water-and-industrial-wastewaters-on-soilplant-health.

[2] Mitra, A., Gupta, S.K., 1999. Effect of sewage water irrigation on essential plant nutrient and element status in vegetable growing areas around Calcutta. Journal of Indian Society of Soil Science, 47: 99-105.

[3] Sulthana, A., Latha, K.C., Ramya, R., Sridhar, R., Balasubramanian, S., 2013. Factor Analysis and Discriminant Analysis of Wastewater Quality in Vidyaranyapuram Sewage Treatment Plant, Mysore, India: A Case Study. Environmental \& Analytical Toxicology. 3-7.

[4] Ghafoor, A., Rauf, A., Arif, M., Muzaffar, W., 1995. Chemical composition of effluent from different industries of the Faisalabad city. Pak. J. Agric. Sci., 31: (4) 367-369.

[5] Aljaloud, A.A., 2010. Reuse of wastewater for irrigation in Saudi Arabia and its effect on soil and plant. Paper presented in 2010 19th World Congress of Soil Science, Soil Solutions for a Changing World $1-6$ August 2010, Brisbane, Australia. 163-166.

[6] Ramesh, M., 2003. Soil and water resource characteristics in relation to land disposal of sewage effluents and suitability of sewage water for irrigation. M.Sc. (Ag.) Thesis Acharya N.G. Ranga Agricultural University, Hyderabad.

[7] Ambika, S. R., Ambica, P. K., Govindaiah., 2010. Crop growth and soil properties affected by sweage water irrigation a review. Agril Reviews. 31 (3): 203-209.

[8] Darvishi, H.H., Manshouri, M., Farahani, H.A., 2010. The effect of irrigation by domestic wastewater on soil properties. J. Soil Sci. Environ. Manag. 1(2):030-033.

[9] Ali, K., Javid, M.A., Javid, M., 1996. Pollution and industrial waste. 6th National Congress Soil Sci., Lahore. 122-131.

[10] Malla, R., Tanaka, Y., Mori, K., Totawat, K.L., 2007. Short term effect of sewage irrigation on chemical buildup in soil and vegetables. The Agric. Engg. Int. The CIGR J. Manuscript LW 07 006. Vol IX. August 2007. Pp 14.

[11] Rattan, R.K., Datta, S.P., Chhonkar, P.K., Suribabu, K., Singh, A.K., (2005). Long-term impact of irrigation with sewage effluents on heavy metal content in soils, crops and groundwater - a case study. Agric. Ecol. Environ. 109: 310-322.

[12] Singh, K.P., Mohon, D., Sinha, S., Dalwani, R., 2004. Impact assessment of treated/untreated wastewater toxicants discharge by sewage treatment plants on health, agricultural, and environmental quality in wastewater disposal area. Chemosphere 55: $227-255$.

[13] Mapanda, F., Mangwayana, E.N., Nyamangara, J., Giller, K.E., 2005. The effect of long-term irrigation using wastewater on heavy metal contents of soils under vegetables in Harare, Zimbabwe. Agric. Ecosyst. And Environ., 107: 151-165. 
[14] Rashid, A., Rahmatullah., Salim. M., 1988. Soil condition and crop factors inducing zinc deficiency in plants. In; Proc. National Seminar on Micronutrients in Soil and Crops in Pakistan, held in Peshawar Dec.13-15-1987. Peshawar; NWFP Agricultural University. p. 94-117.

[15] Qadir, M., A. Ghafoor, S.I. Hssain, G. Murtaza and T. Mahmood. 1999. Copper concentration in city effluents irrigated soils and vegetables. Pak. J. Soil Sci. 97-102.

[16] Sharma, R.K., Agrawal, M., Marshall, F.M., 2006. Heavy metals contamination in vegetables grown in waste water irrigated areas ofVaranasi, India. Bull. Environ. Contamin. Toxicol., 77: 312-318.

[17] Sharma, R.K., Agrawal, M., 2006. Effects of single and combined treatment of $\mathrm{Cd}$ and $\mathrm{Zn}$ on carrots: Uptake and bioaccumulation. 1. Plant Nutr., 29: 1791-1804.

[18] Agarwal, S.K., 2002. Pollution Management, Vol. IV, Heavy metal pollution. A.P.H. Pub. Co., New Dehli. 145-163.

[19] APHA., 1998. Standard methods for examination of water and wastewater, 20th ed. American Public Health Association, Washington, DC, USA.

[20] Hossner, L.R., 1996. Dissolution for total methods of soil analysis elemental analysis, third ed. In: Methods of Soil Analysis. Part 3: Chemical Methods SSSA \& Amer. Soc. of Agron., Madison, WI, 46-64.

[21] Hseu, Z.Y., 2004. Evaluating heavy metal contents in nine composts using four digestion methods. Bioresource Technol., 95: 53-59.

[22] SAS, 2004. Statistical Analysis System, SAS Institute, Inc. Cary., N. C. U. S. A.

[23] Pescod, M.B., 1992. Wastewater treatment and use in agriculture. Bull FAO 47: 125, Rome.

[24] FAO., 1985. Guidelines: land evaluation for irrigated agriculture. Soils Bulletin 55. Food and Agriculture Organization of the United Nations, Rome, Italy.

[25] Bharose, R., Lal, B.S., Singh, K.S., Srivastava, K.P., 2013. Heavy metals pollution in soil-water-vegetation continuum irrigated with ground water and untreated sewage. Bull. Environ. and Sci. Res., 2, (1),pp.1-8.

[26] Singh, R., Singh, D.P., Kumar, N., Bhargava, S.K., Barman, S.C., 2010. Accumulation and translocation of heavy metals in soil and plants from fly ash contaminated area. Environmental Biology 31: 421-430.

[27] Gupta, S., Satpati, S., Nayek, S., \& Garai, D., 2010. Effect of wastewater irrigation on vegetables in relation to bioaccumulation of heavy metals and biochemical changes. Environmental Monitoring and Assessment, 165(1), 169-177.

[28] Saffari, V.R., Saffari, M., 2013. Effect of treated municipal wastewater on bean growth, soil chemical properties, and chemical fractions of zinc and copper. Arab J Geosci $6: 4475-4485$.

[29] Vaseghi, S., Afyuni, M., Shariatmadari, H., Mobli, M., 2005. Effect of sewage sludge on some nutrients concentration and soil chemical properties. Journal of Isfahan Water and Wastewater, 53: 15-19 (in Persian).

[30] Khai, N.M., Tuan, P.T., Vinh, N.C., Oborn, I., 2008. Effects of using wastewater as nutrient sources on soil chemical properties in peri-urban agricultural systems. V.N.U. J.Sci., Earth Sci., (24): 87-95.

[31] Mohammad, M.J., Mazahreh, N., 2003. Changes in soil fertility parameters in response to irrigation of forage crops with secondary treated wastewater. Soil Sci Plant Anal 34:1281-1294.

[32] Mollahoseini, H., 2013. Long term effects of municipal wastewater irrigation on some properties of a semiarid region soil of Iran. International journal of Agronomy and Plant Production. Vol., 4 (5), 1023-1028.

[33] Khaskhoussy, K., Hachicha, M., Kahlaoui, B., Messoudi-Nefzi, B., Rejeb, A., Jouzdan, O., Arselan, A., 2013. Effect of treated wastewater on Soil and Corn Crop in the Tunisian Area. J. Appl. Sci. Res., 9(1): 132-140.

[34] Rusan, M.M.J., S. Hinnawi, L. Rousan, 2007. Long term effect of wastewater irrigation of forage crops on soil and plant quality parameters. Desalination, 215: 143-152.

[35] Mancino, C.F., Pepper, I.L., 1992. Irrigation of turf grass with secondary sewage effluent: soil quality. Agron J 84(4):650-654.

[36] Abedi-Koupai. J., Mostafazadeh-Fard. B., Afyuni, M., Bagheri, M.R., 2006. Effect of treated wastewater on soil chemical and physical properties in an arid region. Plant Soil Environ, 52(8):335-344.

[37] Angin, I., Yaganoglu, A.V., Turan, M., 2005. Effects of long-term wastewater irrigation on soil properties. Sustain Agriculture Journal, 26:31-42.

[38] Galavi, M., Jalali, A., Ramroodi, M., Mousavi, S. R., Galavi, H., 2010. Effects of treated municipal wastewater on soil chemical properties and heavy metal uptake by sorghum (Sorghum bicolor L.). J Agr Sci 2 (3):235-241.

[39] Rana, L., Dhankhar, R., Chhikara, S., 2010. Soil characteristics affected by long term application of sewage wastewater. Int $\mathrm{J}$ Environ Res 4(3):513-518.

[40] Kiziloglu, F.M., Turanb, M., Sahina, U., Kuslua, Y., Dursunc, A., 2008. Effects of untreated and treated wastewater irrigation on some chemical properties of cauliflower (Brassica olerecea L. var. botrytis) and red cabbage (Brassica olerecea L. var. rubra) grown on calcareous soil in Turkey. Agric Water Manage 95(6):716- 724.

[41] Al-Lahham, O., El Assi, N.M., Fayyad, M., .2007. Translocation of heavy metals to tomato (Solanum lycopersicom L.) fruit irrigated with treated wastewater. Scientia Horticulturae, 113: 250-254.

[42] Mapanda, F., Mangwayana, E.N., Nyamangara, J., Giller, K.E., 2005. The effect of long-term irrigation using wastewater on heavy metal contents of soils under vegetables in Harare, Zimbabwe. Agric Ecosyst Environ 107:151-165.

[43] Moazzam, A., Khan, S., Shahid, S., Ataf Khan, M., 2009. Growth, yield and nutrient content of Sunflower (Heliantus Annuus L.) using treated wastewater from wastestabilization ponds. Pak. J. Bot., 41(3): 1391-1399.

[44] Amin, N., Hussain. A., Alamzeb. S., Begum. S., 2013., Accumulation of heavy metals in edible parts of vegetables irrigated with waste water and their daily intake to adults and children, District Mardan, Pakistan. Food Chemi. 136: $1515-1523$ 
[45] Sahay, s., Inam, A., \& Iqbal, S., 2013. Effect of wastewater irrigation on soil, metal tolerance and its remediation by four oil yielding Brassica cultivars. International Journal of Environmental Sciences Volume 4 No.2: 158-170.

[46] Kannaujia, R., \& Singh, S., (2012) Levels, Spatial Distribution and Possible Sources of Heavy Metal Contamination of Suburban Soil in Jhansi. Orient. J. Chem., Vol. 28(4), 1913-1918.
[47] Gupta. N., Khan. D. K., Santra. S. C., 2012. Heavy metal accumulation in vegetables grown in a long term wastewater-irrigated agricultural land of tropical India. Environ Monit Assess 184:6673-6682.

[48] Mahmood, A., Malik, R.N., 2014. Human health risk assessment of heavy metals via consumption of contaminated vegetables collected from different irrigation sources in Lahore, Pakistan. Arabian Journal of Chemistry., 7, 91-99. 